\title{
研究課題別評価
}

\section{1. 研究課題名:}

微生物群によるオーガナイズドバイオモジュール

2. 研究者氏名：橋本 浩一

研究員: 奥 寛雅 ( 研究期間 H.15.04 H.17.03 )

研究員：鏡 慎吾（研究期間 H.15.04 H.15.06）

\section{3. 研究の狙い:}

本研究は、微生物をモジュールとして情報処理機構と結合することで、柔軟かつ多様な機能を 提供する超大規模マイクロシステムの実現を目指すものである。既存のマイクロエレクトロメカニ カルシステム(MEMS)技術では、システムの状態をセンシングすることが困難であり、ひとつのハ 一ドウェアはひとつの機能しか提供できない。しかし、微生物は細胞内にセンサ·アクチュエータを 内蔵する非常に優れたマイクロマシンである。さらに組み替え DNA 技術を視野に入れるとセンサ やアクチュエータの特性はデザイン可能となり、きわめて多様な機能を提供できる可能性がある。 したがって、多数の微生物を協調させるフィードバック制御システムが構築できれば、既存の MEMS の概念を超越するプログラム可能な多機能マイクロシステムが実現できる。本研究は、理 論面では、微生物単体のモデリングと制御理論および多数の微生物からなる群のモデリングと協 調制御理論の開発を目的とする。応用面では、既存のマイクロビジュアルサーボ技術を発展させ、 微生物群協調制御のためのシステムを実現することで超大規模マイクロシステムの基礎技術確 立を目的とする。本研究の本質は、微生物群とコンピュータシステムの融合というまったく新しい 分野の包括的研究であり、その応用分野はライフサイエンス、医療から計測機器までときわめて 広汎である。

\section{4. 研究成果}

本研究ではゾウリムシを対象として研究を進めた。ゾウリムシは微生物の中では研究が進んで おり、その生物学的性質も比較的解明されている。また、研究対象として多くの大学の研究室で たくさんの変位種が維持されており、入手が容易なためである。

本研究の成果を、微生物単体のモデリングと制御、 多数の微生物からなる群のモデリングと協調制御、 マイクロビジュアルサーボ技術の発展、超大規模マイ クロシステムの基礎技術の確立の4つの観点からま とめる。

\section{(1). 微生物単体のモデリングと制御}

最初に、微生物走性のモデルを導出し、走性を利

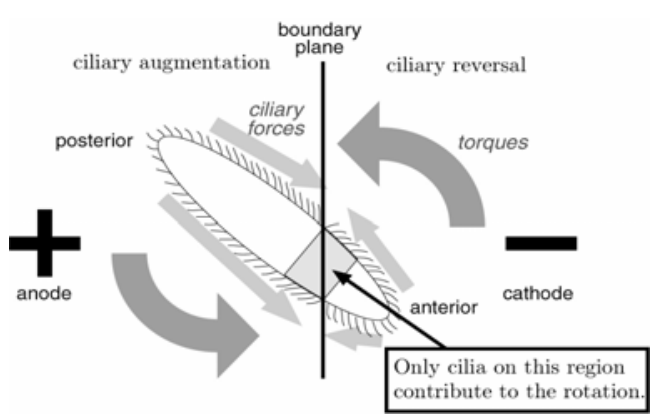
用して運動を制御することを試みた。コンピュータで制御するには電場が最も使いやすいので、本 
研究では、電気走性を利用する。電気走性の定性的説明は次のとおりである。ゾウリムシが電場 方向に対し傾きを持って静止しているとする。このとき、 細胞の陰極に近い部分の繊毛打は、通常とは反転する。 一方、陽極に近い部分の繊毛打は激しくなり、細胞左右 の側面において、推進力の不釣合いが生ずる。これに より細胞遊泳方向が変化し、結果として陰極に進む。本 研究ではこの関係式を定量的にモデル化し、ゾウリムシ の電気走性モデルを導出した。

電気走性を利用すれば、ゾウリムシが泳いでいるプー ルに電位勾配を発生させる仕組みを組み込めば、ゾウ リムシの運動を制御できる。しかし、ゾウリムシの遊泳速 度は秒速 $5 \mathrm{~mm}$ (一秒間に体長の 50 倍)程度と高速であ る。そのために、顕微鏡下のプールを可動式にし、ゾウ リムシが顕微鏡の視野から出ないようにプール位置を 制御するシステムを構築した。高速視覚システムは、1 秒間に 1,000 フレームの画像処理が可能であり、ゾウリ ムシが常に視野の中央に戻るように XY ステージをフィ 一ドバック制御した。これによりゾウリムシを視野から逃 すことなくトラッキングすることができた。

次に、電気刺激デバイスを試作し、ゾウリムシの運動 を制御する実験を行った。ゾウリムシが設定領域から外
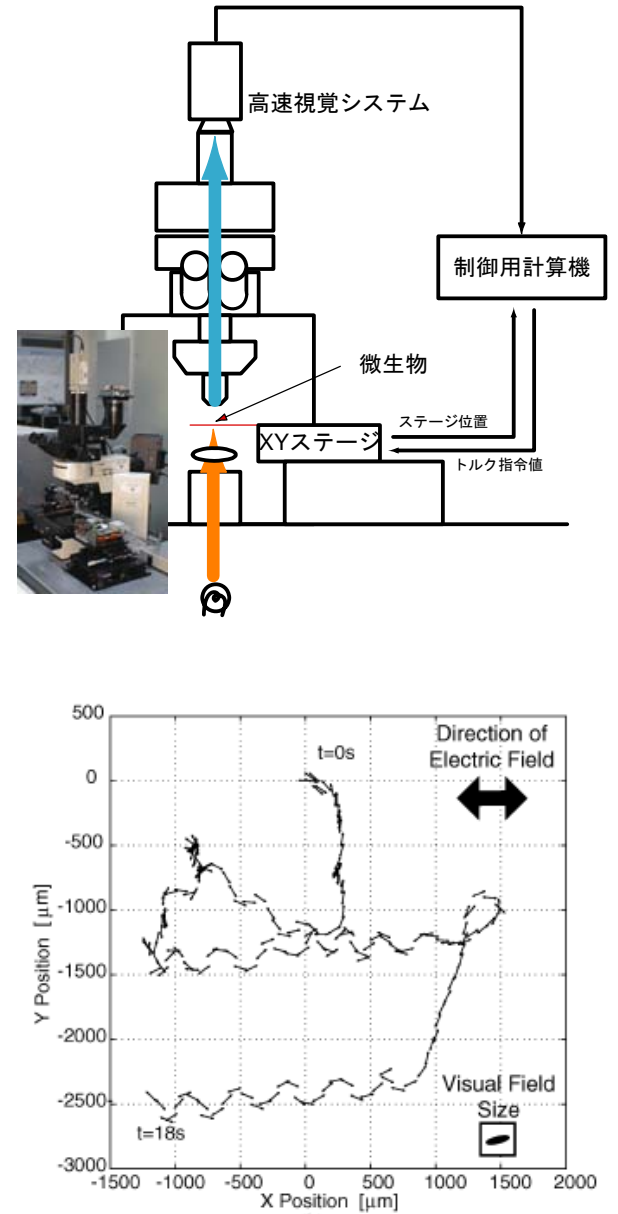
に出ないように電場をかける実験を行った。設定領域(Trap Region)への閉じ込めに成功している ことがわかる。

\section{(2). 多数の微生物からなる群のモデリングと協調制御} 微生物群の制御について考える。微生物の密度が高く なると微生物同士の相互作用が発現し、対流のような現 象が見られることが知られている。本研究では、単個体で の運動モデルに加えて個体相互に作用する影響のモデリ ングを試みた。しかし、今のところこのモデルの導出はで きていない。

多数の個体の制御のために、倍率を下げたマクロレン ズを用いたシステムを構築し、このシステムを用いてポリ スチレンビーズをゾウリムシ群で押す実験を行った。この 実験は, ゾウリムシを用いたマニピュレーションの可能性 を示すものであり、重要な成果である。
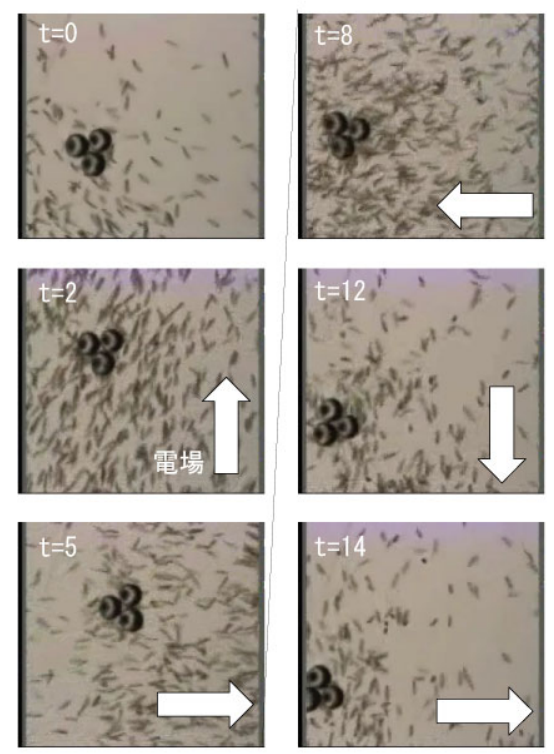
(3). マイクロビジュアルサーボ技術の発展

1 秒間に 1,000 フレーム撮像·画像処理が可能な高速ビジョンシステムを駆使し、マイクロビジュ 
アルサーボシステムを構築した。さらに、光軸方向の移動をト ラッキングするために、焦点面を高速に移動させるレンズを作 成した。現在、XYZ ステージを併用して 3 次元トラッキングの研 究を進めている。

\section{(4). 超大規模マイクロシステムの基礎技術の確立}

大規模マイクロシステムの基盤技術として、微生物を用いた センシングの研究を行った。微生物は刺激に反応して、細胞内 のイオン濃度が変化する。イオン濃度の可視化ができれば、 微生物が反応している刺激の種類と強度がビジョンセンサで 観測できる。そのための基礎作業として、細胞マニピュレーショ ンシステムを導入し、ゾウリムシ体内に蛍光試薬を注入するこ とに成功した。イオン濃度の蛍光観察のための基礎実験に成 功している。

\section{5. 自己評価}

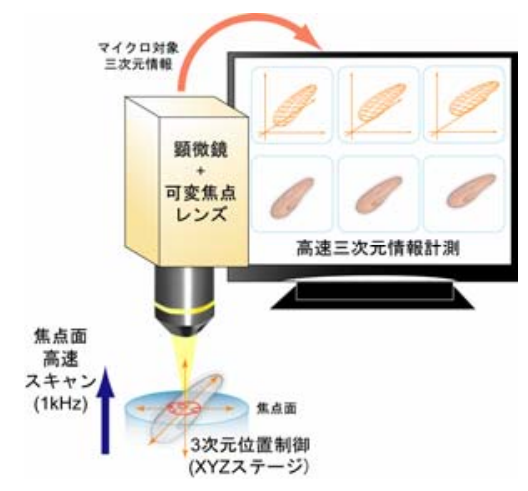

微生物単体のモデリングと制御は、ほぼ完全に達成できた。群行動のモデリングは未完成であ るが、多数の微生物の運動制御は可能性を見出せた。微小物体のマニピュレーションは簡単な 作業は行うことができた。マイクロビジュアルサーボ技術に関しては、可変焦点レンズの開発や焦 点面制御アルゴリズムの開発、XYZ ステージを用いたトラッキングなど、多方面に展開することが できた。大規模マイクロシステムへの基礎となる成果としては、細胞内イオン濃度変化の可視化 について検討しており、微生物センサとしての応用の可能性が考えられる。これは当初計画から 派生した新しい知見である。

以上、要するに、ロボティクスの面から見た微生物制御は着実な成果を挙げたといえるが、生物 の相互作用に関する知見をまとめることはできていない。

\section{6. 研究総括の見解}

微生物の持つ優れたセンサー機能に着目し、その集団と焦点可変顕微鏡·高速画像処理装置 の融合により単細胞生物 (ゾウリムシ)の個体の運動特性を測定しかつ電圧化での可制御性を検 討、柔軟かつ多機能なマイクロシステムの実現を目指す研究を進めた。完成した 3 次元顕微追尾 装置はこの研究を進めるために不可欠であり、その性能は高い評価に值する。培養液中の小物 体を任意の場所に運ばせるなど、この微生物の集団を制御可能なマイクロシステムとみなす研究 も進行中であり、集団としての個体間の協調的側面に焦点を当てた研究を進めることにより更な る発展が期待される。

\section{7. 主な論文等}

\section{論文}

1. Hiromasa Oku, Koichi Hashimoto, and Masatoshi Ishikawa : Variable-focus lens with 1-kHz 
bandwidth, Optics Express, vol. 12, No. 10, pp. 2138-2149, 2004.

2. Naoko Ogawa, Hiromasa Oku, Koichi Hashimoto and Masatoshi Ishikawa: Microrobotic Visual Control of Motile Cells using High-Speed Tracking System, IEEE Transactions on Robotics, vol.21, no.4, pp.704-712, 2005.

3. Hiromasa Oku, Naoko Ogawa, Koichi Hashimoto, and Masatoshi Ishikawa: Two-dimensional tracking of a motile microorganism allowing high-resolution observation with various imaging techniques, Review of Scientific Instruments, vol. 76, no. 3, 2005.

4. Hiromasa OKU, and Masatoshi ISHIKAWA: A Variable-Focus Lens with $1 \mathrm{kHz}$ Bandwidth Applied to Axial-Scan of A Confocal Scanning Microscope, Proc. of the 16th Annual Meeting of the IEEE Lasers \& Electro-Optics Society (LEOS) 2003 (Tucson, U.S.A., Oct. 26-30, 2003), vol. 1, pp. 309-310.

5. Naoko Ogawa, Hiromasa Oku, Koichi Hashimoto, and Masatoshi Ishikawa: Motile Cell Galvanotaxis Control using High-Speed Tracking System, Proc. of IEEE International Conference on Robotics and Automation (ICRA 2004)(New Orleans, USA, 2004.4.28), pp.1646-1651, Apr. 2004.

6. Naoko Ogawa, Hiromasa Oku, Koichi Hashimoto and Masatoshi Ishikawa, Dynamic Model of Paramecium Galvanotaxis for Microrobotic Application. 2005 IEEE International Conference on Robotics and Automation (ICRA 2005) (Barcelona, Spain, 2005.4.19) / Proceedings, pp. 1258-1263, Apr. 2005.

他論文 4 件、口頭発表 20 件

\section{招待講演}

1. 橋本浩一: ロボットにおける視覚と制御, 第 17 回計算力学講演会特別講演, page 3 , 2004.11.19. 